\title{
Effect of Salinity and Potassium Enrichment on Some Growth Attributes in Sugar Beet (Beta vulgaris L.)
}

\author{
Fadi Abbas ${ }^{1}$ and Entessar Al-Jbawi ${ }^{2}$ \\ 1. Homs Agricultural Research Center, General Commission for Scientific Agricultural Research (GCSAR), Damascus, Syria \\ 2. Sugar Beet Research Department, Crops Research Administration, GCSAR, Damascus, Syria
}

\begin{abstract}
A pot experiment was conducted during winter growing season of 2014 at Homs Agriculture Research Center, General Commission for Scientific Researches (GCSAR), Syria. A factorial experiment arranged according to complete randomized block design with six replications was used. A combination of four levels of saline irrigation water (tap water, 2,000, 4,000 and 6,000 ppm), with three K levels (180, 360 and $540 \mathrm{ppm}$ ), was used to evaluate the effects of saline irrigation water and $\mathrm{K}$ enrichment on some growth attributes of two sugar beet varieties (Semper and Alligator). Results showed that all studied growth attributes, i.e., leaf area (LA), leaf number (LN), total dry matter (TDM) and net assimilation rate (NAR) were decreased under salinity stress conditions compared to the control, while K enrichment significantly increased some of the studied characters such as LA, TDM and NAR, but the differences in LN were apparent according to increase in K levels. The variety Semper surpassed significantly the variety Alligator in LA, TDM and NAR. Results also indicated a significant interaction between salinity $\times$ potassium enrichment, varieties $\times$ potassium enrichment and salinity $\times$ varieties.
\end{abstract}

Key words: Salinity, potassium enrichment, growth traits, sugar beet (Beta vulgaris L.).

\section{Introduction}

Sugar beet (Beta vulgaris L., family: Chenopodiaceae) is the second largest crop for sugar production in world after sugar cane; it is generally better adapted to less favorable ecological conditions than sugar cane [1]. Sugar beet is considered an important crop in Syrian crop rotation, which is grown in three dates, i.e., autumn (mid. of Oct.), winter (mid. of Feb.) and summer (mid. of Jul.), in both poor and fertile soils. The cultivation area of sugar beet in Syria was 6,000 ha in 2013, with an average yield of 49.5 t/ha [2]. Salinity of soil is a major abiotic stress that has adverse effects on physiological and metabolic processes of plants leading to decreased growth and yield of plants [3, 4].

Accumulation of excessive amounts of soluble salts in soil is a characteristic in arid and sub-arid regions, although not entirely limited to such areas. The ability

Corresponding author: Entessar Al-Jbawi, Ph.D., research field: plant breeding. of plants to tolerate excess salts in the rhizosphere is of considerable importance in arid and semi-arid regions where salinization of soil usually prevails [5]. Members of Chenopodiaceae family including sugar beet, which has halophyte ancestors, can combat salinity by having osmotic regulating mechanisms due to accumulation of $\mathrm{Na}^{+}$and $\mathrm{Cl}^{-}$in their vacuoles and cytoplasm [6, 7]. The tolerance threshold of sugar beet to salinity is high (7 dS/m) [8]. It is salt sensitive during seed germination and seedling emergence, but in the next stages it is salt tolerant and there are variations in sugar beet genotypes [9].

Abbas et al. [10] evaluated the response of 10 sugar beet genotypes irrigated with saline water, the electrical conductivity $\left(\mathrm{EC}_{\mathrm{w}}\right)$ of the water ranged from $8.4 \mathrm{dS} / \mathrm{m}$ to $10.4 \mathrm{dS} / \mathrm{m}$ during two years and the results revealed a significant variation in the response of the genotypes when irrigated with saline water. Root, top and sugar yields were decreased under saline conditions, but an increase in sugar content and brix occurred under the same conditions. They 
concluded the possibility of growing some genotypes, i.e., Kawemira, Waed, Montebaldo, Brigitta and progress successfully if saline water is the major source of irrigation, as in the eastern area of Syria, in summer time (mid. of Jul.).

Abbas and Al-Jbawi [11] showed that there was significant genotype $\times \mathrm{NaCl} \times$ temperature $\times$ osmotic potentials interaction on germination percentage, germination speed, radicle length, hypocotyl length and fresh weight, indicating that sugar beet seeds responded differently to salt and temperature changes. Also, Abbas et al. [12] found that the growth attributes such as relative growth rate and net assimilation rate (NAR) of some sugar beet genotypes decreased significantly under salt condition, and the decrease in biomass under saline conditions was correlated with the reduction in leaf area (LA), which resulted in decreases of photosynthetic area.

Sugar beet plants grown under salinity stress showed imbalanced nutrient contents in their tissues. The effect of salt stress on the nutrient concentration in the plant varies among elements. Increasing salt concentration in growth media resulted in reducing $\mathrm{K}^{+}$ uptake by sugar beet plants and in turn, $\mathrm{K}^{+}$content in shoots [13]. One approach to minimize effects of salinity is use of nutrient foliar application or nutrient enrichment to increase tolerance of plant to salinity by alleviating $\mathrm{Na}^{+}$and $\mathrm{Cl}^{-}$injury [14]. The beneficial effect of $\mathrm{K}$ fertilization on growth, yield and quality of sugar beet was shown by some previous studies. Abdel-Mawly and Zanouny [5] found that total soluble solids, refinable sugar, purity percentages of root juice, total root yield and top yield of sugar beet plants increased as $\mathrm{K}$ fertilizer increased. Also, Mehrandish et al. [15] showed that $\mathrm{K}$ application increased root yield, shoot yield, impure sugar percent, pure sugar percent and sugar yield.

Abbas et al. [16] performed an experiment on 10 sugar beet genotypes to evaluate their salt tolerance. The results confirmed that $\mathrm{Na}^{+}$content of the leaves and roots was increased in all of the genotypes subjected to salinity. Such an increase in $\mathrm{Na}^{+}$was higher in leaves than in roots. On the other hand, $\mathrm{K}^{+}$ content of the leaves and roots was decreased, and was lower in roots than in leaves. Generally, inorganic solutes $\left(\mathrm{Na}^{+}\right.$and $\left.\mathrm{K}^{+}\right)$were found in higher amounts in leaves than in roots. Also, the genotype Kawimera was introduced as the most salt-tolerant and Tigris was pinpointed as the most sensitive one. Due to the importance of the subject, the objective of this study was to evaluate the effects of saline irrigation water and application of $\mathrm{K}$ fertilizer on some growth attributes for two sugar beet varieties in pot experiment.

\section{Materials and Methods}

The experiment was carried out during winter season 2014, at Homs Agricultural Center, General Commission for Scientific Agriculture Researches (GCSAR), Syria. The site has a latitude of $34.7324^{\circ} \mathrm{N}$, and longitude of $36.7137^{\circ} \mathrm{E}$. A clay loam soil was used in order to assess some growth attributes for two sugar beet (Beta vulgaris L.) varieties (Semper and Alligator) under irrigation with saline water and application of $\mathrm{K}$ fertilizer.

Pots of $20 \mathrm{~cm}$ diameter and $30 \mathrm{~cm}$ in depth were used which were filled with $14 \mathrm{~kg}$ of soil. Table 1 shows some properties and texture of the studied soil surface layer $0-30 \mathrm{~cm}$. Pots were arranged in a randomized complete block design (RCBD) including 24 treatments, which were combination of four saline water levels, three $\mathrm{K}$ levels and two varieties with six replicates. Three months before planting, $\mathrm{P}$ fertilizer was added at a level of $2.5 \mathrm{~g} /$ pot, as superphosphate $\left(50 \% \mathrm{P}_{2} \mathrm{O}_{5}\right)$. N was added at a level of $120 \mathrm{~kg} \mathrm{~N} / \mathrm{ha}$ supplied as $\mathrm{NH}_{4} \mathrm{NO}_{2}(33.5 \% \mathrm{~N})$, which equals 1.4 $\mathrm{g} /$ pot immediately after thinning. Three seeds of each variety were planted on Jan. 16th, 2014. The plants were thinned once after $24 \mathrm{~d}$ at a stage of two real leaves appearance.

After thinning, sugar beet plants were subjected to four levels of salt concentrations ( $\mathrm{NaCl}$ solutions) till 
the end of experiment. The four salinity levels were 0 (tap water as control), 2,000, 4,000 and 6,000 ppm, the irrigation subjected when the field capacity reached $65 \%$ by weighting every pot daily. $\mathrm{K}$ (48\% $\mathrm{K}_{2} \mathrm{O}$ ) levels were 180, 360 and $540 \mathrm{ppm}$ of $\mathrm{K}_{2} \mathrm{SO}_{4}(48 \%$ $\mathrm{K}_{2} \mathrm{O}$ ) that were added $5 \mathrm{~d}$ after thinning. Rival and Alligator varieties were used. Two samples were selected during the growth period, i.e., $35 \mathrm{~d}$ and $50 \mathrm{~d}$ after emergence (three replications used in each sampling).

The following attributes were determined:

The fresh weight of the aerial parts and roots was determined immediately after harvesting. Leaf number (LN) and LA were estimated as follows:

$\mathrm{LN}$ : the number of green leaves with a lamina length greater than $6 \mathrm{~cm}$ was considered [17].

LA: ( $\mathrm{cm}^{2} /$ plant) was obtained using the equation proposed by Gohari and Rouhy [18].

$$
\begin{aligned}
& \mathrm{LA}=-201.2558+12.401 L+13.35 W \quad(L>16 \mathrm{~cm})(1) \\
& \mathrm{LA}=6.4736+0.84138 L \cdot W \quad(L<16 \mathrm{~cm})
\end{aligned}
$$

where $L$ and $W$ are the largest length and width of lamina in centimeters.

Tops and roots were dried for $48 \mathrm{~h}$ at $75{ }^{\circ} \mathrm{C}$ in a conventional oven (A23B7/03, Procter and Gamble Co., Europe) and weighed. Dry matter partitioning of the tops and roots was determined after drying the whole samples.

$$
\begin{aligned}
& \text { NAR (g/m²/day) [19]: } \\
& \qquad \operatorname{NAR}=\frac{\left(W_{2}-W_{1}\right)\left(\log _{e} A_{2}-\log _{e} A_{1}\right)}{\left(T_{2}-T_{1}\right)\left(A_{2}-A_{1}\right)}
\end{aligned}
$$

where $W_{1}, W_{2}$ and $A_{1}, A_{2}$ refer to dry weight to plant and LA at time $T_{1}$ and $T_{2}$ (first and second sampling), respectively.

Statistical analysis: analysis of variance (ANOVA) appropriate for randomized complete block design (RCBD) with three factors was applied [20]. The treatment means were compared using least significant difference (LSD) procedures at $5 \%$ level using GeneStat Computer Program v.12.

\section{Results}

3.1 Effect of Irrigation with Salt Solutions, Foliar Spraying with K, and Varieties on LN, LA, Total Dry Matter (TDM) and NAR

Data presented in Table 1 show that LN, LA, TDM and NAR were significantly decreased by increasing irrigation water salinity levels as compared with the control treatment (tap water). The reduction in LN was noticed at 6,000 ppm level of salinity, while this character was not differed at the other levels.

The studied growth attributes reduced with increasing salt concentration of irrigation water. Such reduction might be due to lowering of the external water potential or the effect of ion toxicity on metabolic processes. At high salt levels, the availability of water becomes so critically low hence growth parameters are inhibited. These results are in agreement with those obtained by Abbas et al. [12], who found that under salinity stress, LA in 10 genotypes decreased by $8.94 \%$ as compared to control after $120 \mathrm{~d}$ from sowing period. In addition, NAR decreased in all genotypes by an average of $26.47 \%$ as compared to control. $\mathrm{K}$ enrichment significantly increased some of the studied characters such as LA, TDM and NAR, while the differences in LN were apparent according to increasing $\mathrm{K}$ levels, this might be due to the role of $\mathrm{K}$ in regulating osmotic potential, and increasing water uptake ability of sugar beet plants [21].

These results are consistent with Monreal et al. [22] who mentioned that $\mathrm{K}$ application prevented the depletion of the nutrient in the leaves that may cause reduction in photosynthetic rate and consequently

Table 1 Mechanical and chemical analysis of the soil.

\begin{tabular}{llllllllll}
\hline Sand (\%) & Silt (\%) & Clay (\%) & $\begin{array}{l}\text { Organic matter } \\
(\%)\end{array}$ & $\begin{array}{l}\text { Electrical } \\
\text { conductivity } \\
(\mathrm{EC})(\mathrm{dS} / \mathrm{m})\end{array}$ & $\mathrm{CaCO}_{3}(\%)$ & $\mathrm{P}_{2} \mathrm{O}_{5}(\mathrm{ppm})$ & $\mathrm{KOH}(\mathrm{ppm})$ & $\mathrm{N}(\mathrm{ppm}) \mathrm{B}(\mathrm{ppm})$ \\
\hline 31.26 & 28.64 & 40.10 & 1.38 & 0.34 & 7.5 & 2.9 & 20.5 & 180 & 64.8 \\
\hline
\end{tabular}


reduced growth characters. Moreover, $\mathrm{K}$ may help in maintaining a normal balance between carbohydrates and proteins and absorbing more $\mathrm{K}^{+}$cations replaced with $\mathrm{Na}^{+}$, which caused the injury to cell and plant behavior. The differences in the two varieties in $\mathrm{LN}$ were clear after $35 \mathrm{~d}$ and $50 \mathrm{~d}$, besides TDM and NAR. Data presented in Table 2 show that the variety Semper surpassed significantly Alligator in LA, TDM and NAR. These differences might be due to the genotypic variation existing between those two sugar beet varieties. Under salinity conditions, differences were noticed in varieties behavior. In this respect, Ahmad et al. [23] reported that sugar beet varieties differed significantly for all growth and yield characters.

\subsection{Effect of Interaction between Salinity and $K$} Enrichment Levels on LN, LA, TDM and NAR

Data presented in Table 3 show the interaction between salinity and $\mathrm{K}$ enrichment on some growth attributes after $35 \mathrm{~d}$ and $50 \mathrm{~d}$ after emergence. The significant differences in LN were noticed at 6,000 ppm level only, and there were no differences in the interaction between $\mathrm{K}$ levels and the other salinity levels. On the other hand, LA and TDM decreased significantly with increasing salinity level, and increased with increasing $\mathrm{K}$ levels. The highest values for LA and TDM after $35 \mathrm{~d}$ and $50 \mathrm{~d}$ were recorded in the interaction (irrigation with tap water and enrichment with 540 ppm $\mathrm{K}_{2} \mathrm{O}$ ). The lowest values were recorded in the interaction (irrigation with 6,000 ppm and enrichment with 180 ppm $\mathrm{K}_{2} \mathrm{O}$ ).

Similar results were noticed for NAR; this character decreased significantly with increasing salinity levels, and increased with increasing $\mathrm{K}$ levels. The highest values for NAR were recorded in the interaction (irrigation with tap water and enrichment with 360 ppm and 540 ppm $\mathrm{K}_{2} \mathrm{O}$ ) without any significant differences between these interactions. Also, the lowest values were recorded in the interaction of (irrigation with 6,000 ppm and K enrichment with 180 ppm $\mathrm{K}_{2} \mathrm{O}$ ).

Table 2 Effect of salinity, K enrichment levels and sugar beet varieties on leaf number (LN), leaf area (LA), total dry matter (TDM) and net assimilation rate (NAR) after $35 \mathrm{~d}, 50 \mathrm{~d}$ of sowing.

\begin{tabular}{|c|c|c|c|c|c|c|c|}
\hline & \multicolumn{2}{|c|}{$\begin{array}{c}\text { LN } \\
\text { (leaf/plant) }\end{array}$} & \multicolumn{2}{|c|}{$\begin{array}{c}\text { LA } \\
\text { (cm²/plant) }\end{array}$} & \multicolumn{2}{|c|}{$\begin{array}{c}\text { TDM } \\
\text { (g/plant) }\end{array}$} & \multirow{2}{*}{$\begin{array}{l}\text { NAR } \\
-\left(\mathrm{g} / \mathrm{m}^{2} / \text { day }\right)\end{array}$} \\
\hline & $35 \mathrm{~d}$ & $50 \mathrm{~d}$ & $35 \mathrm{~d}$ & $50 \mathrm{~d}$ & $35 \mathrm{~d}$ & $50 \mathrm{~d}$ & \\
\hline \multicolumn{8}{|c|}{ Salinity level (ppm) } \\
\hline 0 & 6.2 & 12.5 & 241.4 & 647.0 & 4.38 & 12.88 & 10.32 \\
\hline 2,000 & 6.3 & 12.3 & 208.7 & 494.8 & 4.10 & 10.34 & 9.41 \\
\hline 4,000 & 6.6 & 12.1 & 177.8 & 305.5 & 3.60 & 7.30 & 7.79 \\
\hline 6,000 & 4.3 & 8.9 & 146.1 & 188.9 & 2.59 & 4.66 & 6.23 \\
\hline $\mathrm{LSD}_{0.05}$ & 0.34 & 0.38 & 6.76 & 14.12 & 0.181 & 0.803 & 1.324 \\
\hline Probability & $<0.001$ & $<0.001$ & $<0.001$ & $<0.001$ & $<0.001$ & $<0.001$ & $<0.001$ \\
\hline \multicolumn{8}{|c|}{$\mathrm{K}_{2} \mathrm{O}$ levels (ppm) } \\
\hline 180 & 5.8 & 11.4 & 183.1 & 388.0 & 3.16 & 7.41 & 7.40 \\
\hline 360 & 5.8 & 11.4 & 196.6 & 416.3 & 3.77 & 9.29 & 8.85 \\
\hline 540 & 5.9 & 11.5 & 200.8 & 422.9 & 4.08 & 9.70 & 9.06 \\
\hline $\mathrm{LSD}_{0.05}$ & 0.30 & 0.33 & 5.85 & 12.23 & 0.157 & 0.696 & 1.146 \\
\hline Probability & 0.437 & 0.739 & $<0.001$ & $<0.001$ & $<0.001$ & $<0.001$ & 0.010 \\
\hline \multicolumn{8}{|l|}{ Varieties } \\
\hline Semper & 5.8 & 11.4 & 204.9 & 430.3 & 3.88 & 9.22 & 8.40 \\
\hline Alligator & 5.8 & 11.4 & 182.1 & 387.8 & 3.46 & 8.38 & 8.47 \\
\hline $\mathrm{LSD}_{0.05}$ & 0.24 & 0.27 & 4.78 & 9.99 & 0.128 & 0.568 & 0.936 \\
\hline Probability & 0.495 & 0.839 & $<0.001$ & $<0.001$ & $<0.001$ & 0.004 & 0.889 \\
\hline
\end{tabular}


Table 3 Effect of interaction between salinity and $\mathrm{K}$ enrichment levels on LN, LA, TDM and NAR after $35 \mathrm{~d}, 50 \mathrm{~d}$ of sowing.

\begin{tabular}{|c|c|c|c|c|c|c|c|c|}
\hline \multirow{2}{*}{$\begin{array}{l}\text { Salinity level } \\
\text { (ppm) }\end{array}$} & \multirow{2}{*}{$\begin{array}{l}\text { K levels } \\
\text { (ppm) }\end{array}$} & \multicolumn{2}{|c|}{$\begin{array}{c}\mathrm{LN} \\
\text { (leaf/plant) }\end{array}$} & \multicolumn{2}{|c|}{$\begin{array}{c}\mathrm{LA} \\
\text { (cm/plant) }\end{array}$} & \multicolumn{2}{|c|}{$\begin{array}{c}\text { TDM } \\
\text { (g/plant) }\end{array}$} & \multirow{2}{*}{$\begin{array}{l}\text { NAR } \\
\text { (g/m²/day) }\end{array}$} \\
\hline & & $35 \mathrm{~d}$ & $50 \mathrm{~d}$ & $35 \mathrm{~d}$ & $50 \mathrm{~d}$ & $35 \mathrm{~d}$ & $50 \mathrm{~d}$ & \\
\hline \multirow{3}{*}{0} & 180 & 6.33 & 12.83 & 232.2 & 622.5 & 3.67 & 10.51 & 8.65 \\
\hline & 360 & 6.17 & 12.33 & 245.0 & 656.6 & 4.69 & 14.05 & 11.25 \\
\hline & 540 & 6.00 & 12.33 & 246.9 & 661.8 & 4.80 & 14.10 & 11.05 \\
\hline \multirow{3}{*}{2,000} & 180 & 6.33 & 12.17 & 198.0 & 468.3 & 3.52 & 8.87 & 8.52 \\
\hline & 360 & 6.33 & 12.17 & 214.2 & 509.2 & 4.56 & 11.86 & 10.80 \\
\hline & 540 & 6.33 & 12.50 & 213.7 & 506.9 & 4.23 & 10.30 & 8.90 \\
\hline \multirow{3}{*}{4,000} & 180 & 6.17 & 12.17 & 167.9 & 288.5 & 3.18 & 6.30 & 6.97 \\
\hline & 360 & 6.67 & 12.00 & 179.3 & 308.1 & 3.40 & 6.74 & 6.98 \\
\hline & 540 & 6.83 & 12.00 & 186.2 & 320.0 & 4.22 & 8.87 & 9.42 \\
\hline \multirow{3}{*}{6,000} & 180 & 4.33 & 8.50 & 134.2 & 172.7 & 2.29 & 3.95 & 5.44 \\
\hline & 360 & 4.00 & 9.00 & 147.7 & 191.1 & 2.41 & 4.53 & 6.36 \\
\hline & 540 & 4.67 & 9.17 & 156.4 & 202.7 & 3.08 & 5.51 & 6.88 \\
\hline $\mathrm{LSD}_{0.05}$ & & 0.595 & 0.656 & 11.71 & 24.46 & 0.314 & 1.391 & 2.293 \\
\hline Probability & & 0.145 & 0.211 & 0.918 & 0.857 & $<0.001$ & 0.002 & 0.216 \\
\hline
\end{tabular}

Table 4 Effect of interaction between salinity and varieties on LN, LA, TDM and NAR after $35 \mathrm{~d}, 50 \mathrm{~d}$ of sowing.

\begin{tabular}{|c|c|c|c|c|c|c|c|c|}
\hline \multirow{2}{*}{$\begin{array}{l}\text { Salinity level } \\
\text { (ppm) }\end{array}$} & \multirow[t]{2}{*}{ Varieties } & \multicolumn{2}{|c|}{$\begin{array}{c}\text { LN } \\
\text { (leaf/plant) }\end{array}$} & \multicolumn{2}{|c|}{$\begin{array}{c}\text { LA } \\
\left(\mathrm{cm}^{2} / \text { plant }\right)\end{array}$} & \multicolumn{2}{|c|}{$\begin{array}{c}\text { TDM } \\
\text { (g/plant) }\end{array}$} & \multirow{2}{*}{$\begin{array}{l}\text { NAR } \\
\text { (g/m²/day) }\end{array}$} \\
\hline & & $35 \mathrm{~d}$ & $50 \mathrm{~d}$ & $35 \mathrm{~d}$ & $50 \mathrm{~d}$ & $35 \mathrm{~d}$ & $50 \mathrm{~d}$ & \\
\hline \multirow{2}{*}{0} & Semper & 6.2 & 12.4 & 247.3 & 662.7 & 4.55 & 13.08 & 10.09 \\
\hline & Alligator & 6.1 & 12.6 & 235.5 & 631.3 & 4.22 & 12.69 & 10.54 \\
\hline \multirow{2}{*}{2,000} & Semper & 6.1 & 12.4 & 218.7 & 519.6 & 4.23 & 10.67 & 9.22 \\
\hline & Alligator & 6.6 & 12.1 & 198.6 & 470.0 & 3.97 & 10.02 & 9.59 \\
\hline \multirow{2}{*}{4,000} & Semper & 6.7 & 12.0 & 191.0 & 328.2 & 3.90 & 7.98 & 8.02 \\
\hline & Alligator & 6.4 & 12.1 & 164.6 & 282.9 & 3.30 & 6.63 & 7.57 \\
\hline \multirow{2}{*}{6,000} & Semper & 6.2 & 8.9 & 162.7 & 210.6 & 2.83 & 5.16 & 6.28 \\
\hline & Alligator & 6.4 & 8.9 & 129.5 & 167.1 & 2.35 & 4.17 & 6.18 \\
\hline $\mathrm{LSD}_{0.05}$ & & 0.59 & 0.54 & 9.56 & 19.97 & 0.257 & 1.136 & 1.872 \\
\hline Probability & & 0.203 & 0.603 & 0.019 & 0.607 & 0.267 & 0.661 & 0.891 \\
\hline
\end{tabular}

Deinlein et al. [24] stated that $\mathrm{K}$ is considered a major osmotically active solute of plant cell, where it enhanced water uptake and root permeability and acted as a guard cell controller, besides its role in increasing water use. So, one approach to minimize the adverse effects of salinity on plant growth is $K$ application to increase salinity tolerance by alleviating $\mathrm{Na}^{+}$and $\mathrm{Cl}^{-}$injury to plants [25]. In this study, $\mathrm{K}$ positively affected all the growth attributes and mitigates the negative impact of salinity on growth. These results are consistent with the studies done by Abdel-Mawly and Zanouny [5] and Abbas et al. [12].
3.3 Effect of Interaction between Salinity and Varieties on LN, LA, TDM and NAR

Data presented in Table 4 show the interaction between salinity and varieties on some growth attributes after $35 \mathrm{~d}$ and $50 \mathrm{~d}$ after emergence, where this interaction was not significant for $\mathrm{LN}$ after $35 \mathrm{~d}$ but ranged between 6.1 and 6.7. It was noticed that there were no differences between the two varieties, but increasing salinity levels of irrigation reduced LA and TDM. However, Semper variety recorded the highest values for these growth criteria under tap water 
Table 5 Effect of interaction between $\mathrm{K}$ enrichment and varieties on LN, LA, TDM and NAR after $35 \mathrm{~d}, 50 \mathrm{~d}$ of sowing.

\begin{tabular}{|c|c|c|c|c|c|c|c|c|}
\hline \multirow{2}{*}{$\begin{array}{l}\text { K level } \\
\text { (ppm) }\end{array}$} & \multirow[t]{2}{*}{ Varieties } & \multicolumn{2}{|c|}{$\begin{array}{c}\mathrm{LN} \\
\text { (leaf/plant) }\end{array}$} & \multicolumn{2}{|c|}{$\begin{array}{c}\mathrm{LA} \\
\left.\text { ( } \mathrm{cm}^{2} / \text { plant }\right) \\
\end{array}$} & \multicolumn{2}{|c|}{$\begin{array}{c}\text { TDM } \\
\text { (g/plant) }\end{array}$} & \multirow{2}{*}{$\begin{array}{l}\text { NAR } \\
\text { (g/m²/day) }\end{array}$} \\
\hline & & $35 \mathrm{~d}$ & $50 \mathrm{~d}$ & $35 \mathrm{~d}$ & $50 \mathrm{~d}$ & $35 \mathrm{~d}$ & $50 \mathrm{~d}$ & \\
\hline \multirow{2}{*}{180} & Semper & 5.7 & 11.3 & 189.1 & 398.9 & 3.33 & 7.67 & 7.49 \\
\hline & Alligator & 5.9 & 11.6 & 177.1 & 377.1 & 3.00 & 7.14 & 7.30 \\
\hline \multirow{2}{*}{360} & Semper & 5.9 & 11.4 & 210.2 & 441.6 & 3.94 & 9.59 & 8.55 \\
\hline & Alligator & 5.7 & 11.3 & 182.9 & 390.9 & 3.59 & 9.00 & 9.15 \\
\hline \multirow{2}{*}{540} & Semper & 5.8 & 11.7 & 215.4 & 450.3 & 4.37 & 10.40 & 9.17 \\
\hline & Alligator & 6.1 & 11.3 & 186.1 & 395.5 & 3.79 & 8.99 & 8.96 \\
\hline $\mathrm{LSD}_{0.05}$ & & 0.42 & 0.46 & 8.28 & 17.30 & 0.222 & 0.984 & 1.621 \\
\hline Probability & & 0.161 & 0.130 & 0.008 & 0.018 & 0.212 & 0.365 & 0.715 \\
\hline
\end{tabular}

(control) irrigation conditions, while the lowest values were recorded in Alligator variety irrigated with 6,000 ppm.

NAR value decreased with increasing salinity levels of irrigation, but at the same level, differences between the two varieties were not significant, and the differences if existed may be due to their relative tolerance to salinity, as obtained by Dadkhah and Grrifiths [26]. The highest values for NAR were under tap water irrigation, while the lowest values were recorded with 6,000 ppm irrigation.

\subsection{Effect of Interaction between $K$ Enrichment and Varieties on LN, LA, TDM and NAR}

Data presented in Table 5 show the interaction between $\mathrm{K}$ levels and varieties on some growth attributes after $35 \mathrm{~d}$ and $50 \mathrm{~d}$ after emergence. The differences in $\mathrm{LN}$ after $35 \mathrm{~d}$ and $50 \mathrm{~d}$ were not significant. It ranged between 5.7-6.1 leaf/plant after $35 \mathrm{~d}$, and 11.3-11.7 leaf/plant after $50 \mathrm{~d}$. In each variety, increasing $\mathrm{K}$ level increased LA and TDM with superiority to Semper. However, Semper variety recorded the highest values for these growth criteria under $540 \mathrm{ppm} \mathrm{K}_{2} \mathrm{O}$, while the lowest values were recorded in Alligator variety under $180 \mathrm{ppm} \mathrm{K}_{2} \mathrm{O}$. NAR value also increased with increasing $\mathrm{K}$ level, but at the same level, differences between the two varieties were not significant.

\section{Disscussion}

Results showed that LN was less affected than LA by salinity. It is suggested that most of the reduction in plant LA was caused by the inhibition of leaf expansion. This is consistent with the results of previous studies, which showed that high levels of salinity decreased LA due to the combination of decrease in cell number and cell size [26]. Munns and Termaat [27] demonstrated that for a given amount of $\mathrm{NaCl}$ transport to the shoot, reduction in leaf expansion results in the same proportional increase in the leaf $\mathrm{NaCl}$ concentration.

The decreased biomass weights of plants under saline conditions are correlated with the reduced LA, which results in decreases of photosynthetic area [28]. It is thought that a decreased photosynthesis under stress could reduce shoot growth and development, leading to lower biomass production compared to control [29], because it is well known that halophytes tolerate saline conditions but with a reduction in growth rate, besides the decrease in dry matter accumulation is mainly due to increase in sodium under high salt stress causing a reduction in the activity of $\mathrm{CO}_{2}$ fixation during photosynthesis and a decrease in the enzymatic activity of the metabolic processes. Different cultivars of the same plant had different behavior toward salt tolerance [30, 31]. The obtained results indicated that NAR of the two genotypes decreased significantly under salt condition, this might be due to the osmotic inhibition of water absorption, accumulation of certain ions in high concentration in plant tissues and alteration of the mineral balance of plants, and/or due to the reduction 
in photosynthetic activity and carbohydrates metabolism.

The positive effect of $\mathrm{K}$ on growth may be due to the prevalent $K$ action in plants and its role in maintenance of the ionic balance in cell, and bounds ionically to enzyme pyruvate kinase which is essential in respiration and carbohydrate metabolism [32]. However, the salt tolerance in plants increased by increasing $\mathrm{K}$ uptake which leads to increasing $\mathrm{K} / \mathrm{Na}$ ratio in plant cells. Moreover, $\mathrm{K}$ plays an important role in regulating osmotic potential, increasing water uptake ability of sugar beet plants [21]. They added that, foliar application with $\mathrm{K}$ could be used to avoid the depletion of this nutrient in the leaves that may cause reduction in photosynthetic rate and consequently reduce growth characters. Moreover, it is involved in activating a wide range of enzyme systems.

\section{Conclusions}

The foregoing discussion showed that all studied growth attributes LA, LN, TDM and NAR were decreased under salinity stress conditions compared to the control, and $\mathrm{K}$ enrichment significantly increased some of the studied characters such as LA, TDM and NAR, while the differences in LN were apparent according to increasing $\mathrm{K}$ levels. Also, the results confirm that the genotypes differed significantly in all studied attributes except in LN and NAR under salt conditions.

The results of the study recommended further studies to correlate the yield with yield components under similar conditions to determine the most tolerant genotype.

\section{References}

[1] EL-Refaey, R. A., El-Seidy, E. H., EL-Geddawy, I. H., and EL-Sayed, H. M. 2012. "Phenotypic and Genotypic Stability for Some Sugar Beet Genotypes.” In Proc. of the 13th International Conf. Agron., Fac. of Agic., Benha Univ., Egypt, September 9-10, 2012, 317-31.

[2] Al Jbawi, E. M., Al Geddawi, S., and Alesha, G. 2015. "Quality Changes in Sugar Beet (Beta vulgaris L.) Roots during Storage Period in Piles.” International Journal of $\begin{array}{llll}\text { Environment } & 4 & \text { (4): }\end{array}$ doi:http://dx.doi.org/10.3126/ije.v4i4.14101.

[3] Azizpour, K., Shakiba, M. R., Khosh, K. S. N., Alyari, H., Moghaddam, M., Esfandiari, E., and Pessarakli, M. 2010. "Physiological Response of Spring Durum Wheat Genotypes to Salinity.” J. Plant Nut. 33: 859-73.

[4] Merwad, A. M. A. 2015. "Effect of Potassium Fertilization and Salicylic Acid on Yield, Quality and Nutrient Uptake of Sugar Beet (Beta vulgaris L.) Grown in Saline Soil.” Malaysian Journal of Soil Science 19: 95-105.

[5] Abdel-Mawly, S. E., and Zanouny, I. 2004. "Response of Sugar Beet (Beta vulgaris L.) to Potassium Application and Irrigation with Saline Water." Ass. Univ. Bull. Environ. Res. 7 (1): 123-36.

[6] Subbarao, G. V., Wheeler, R. M., Levine, L. H., and Stutte, G. W. 2001. "Glycine Betaine Accumulation, Ionic and Water Relations of Red Beet at Contrasting Levels of Sodium Supply.” Journal of Plant Physiology 158: 767-76.

[7] Ghoulam, C., Foursy, A., and Fares, K. 2002. "Effect of Salt Stress on Growth, Inorganic Ions and Proline Accumulation in Relation of Osmotic Adjustment in Five Sugar Beet Cultivars.” Journal of Environment and Experimental Botany 47: 39-50.

[8] Katerji, N., Van-Hoorn, J. W., Hamdy, A., and Mastroili, M. 1997. "Osmotic Adjustment of Sugar Beet in Response to Soil Salinity and Its Influence on Stomatal Conductance, Growth and Yield.” Journal of Agriculture and Water Management 34: 557-69.

[9] Abbas, F., Mohanna, A., Al-Lahham, G., and Al-Jbawi, E. 2009. "Laboratory Screening Tool for Selecting Sugar Beet, Beta vulgaris L. Genotypes under Salinity Stress.” In Proceeding of the 7th Conference of General Commission for Scientific Agricultural Research (GCSAR), 34.

[10] Abbas, F., Mohanna, A., Al-Lahham, G., Al-Jbawi, E., and Al-Jasem, Z. 2011. "Evaluation the Response of Some Sugar Beet (Beta vulgaris L.) Genotypes under Saline Water Irrigation Conditions.” Arab Journal for Dry Environments 4 (1): 93-105.

[11] Abbas, F., and Al-Jbawi, E. 2013. "Effect of Temperature, Osmotic Potential Induced by $\mathrm{NaCl}$ and PEG-6000 on Germination and Seedling Growth of Sugar Beet (Beta vulgaris L.).” Persian Gulf Crop Protection 2 (4): 60-73.

[12] Abbas, F., Al-Jbawi, E., and Ibrahim, M. 2014. "Growth and Chlorophyll Fluorescence under Salinity Stress in Sugar Beet (Beta vulgaris L.).” International Journal of Environment 3 (1): 1-9.

[13] Zaki, N. M., Hassanein, M. S., Ahmed Ebtsam, A. G., El-Housini, A., and Tawfik, M. M. 2014. "Foliar 

in Sugar Beet (Beta vulgaris L.)

Application of Potassium to Mitigate the Adverse Impact of Salinity on Some Sugar Beet Varieties. Effect on Yield and Quality.” Middle East Journal of Agriculture Research 3 (3): 448-60.

[14] Tzortzakis, N. G. 2009. "Influence of $\mathrm{NaCl}$ and Calcium Foliar Spray on Lettuce and Endive Growth Using Nutrient Film Technique.” International Journal of Vegetable Science 15: 1-13.

[15] Mehrandish, M., Moeini, M. J., and Armin, M. 2012. "Sugar Beet (Beta vulgaris L.) Response to Potassium Application under Full and Deficit Irrigation.” European J. of Experimental Biology 2 (6): 2113-9.

[16] Abbas, F., Mohanna, A., Al-Lahham, G., and Al-Jbawi, E. 2012. "Osmotic Adjustment in Sugar Beet under Salinity Stress.” Journal of Sugar Beet 28 (1): 37-43. (in Persian)

[17] Rinaldi, M. 2003. "Variation of Specific Leaf Area for Sugar Beet Depending on Sowing Date and Irrigation.” Ital. J. Argon. 7 (1): 23-32.

[18] Gohari, G., and Rouhy, A. V. 1993. "Estimation of Leaf Area in Sugar Beet.” Journal of Sugar Beet 9: 1-12.

[19] Radfords, P. J. 1967. "Growth Analysis Formulae, Their Use and Abuse.” Crop Sci. 7: 171-5.

[20] Gomez, K. A., and Gomez, A. A. 1984. Statistical Procedures for Agricultural Research, 2nd ed. New York: John Wiley and Sons Inc., 680.

[21] Zengin, M., Fatma, G., Atilla, M. Y., and GezGin, S. 2009. "Effect of Potassium Magnesium, and Sulphur Containing Fertilizers on Yield and Quality of Sugar Beets (Beta vulgaris L.).” Turk J. Agric. 33: 495-502.

[22] Monreal, J. A., Jimenez, E. T., Remesal, E., Morillo-Velarde, R., Garcia-Maurino, S., and Echevarria, C. 2007. "Proline Content of Sugar Beet. Storage Roots: Response to Water Deficit and Nitrogen Fertilization at Field Conditions.” Environ. Exp. Bot. 60: 267.

[23] Ahmad, S., Zubair, M., Iqbal, N., Cheema, N. M., and Mahmood, K. 2012. "Evaluation of Sugar Beet Hybrid
Varieties under Thal-Kumbi.” Soil Series of Pakistan. Int. J. Agric. Biol. 14: 605-8.

[24] Deinlein, U., Stephan, A. B., Horie, T., Luo, W., Xu, G., and Schroeder, J. I. 2014. "Plant Salt-Tolerance Mechanisms.” Trends in Plant Science 19 (6): 371-9.

[25] Koyro, H. W. 2006. "Effect of Salinity on Growth, Photosynthesis, Water Relations and Solute Composition of the Potential Cash Crop Halophyte Plantago coronopus (L.).” Environ. Exp. Bot. 56: 136-46.

[26] Dadkhah, A. R., and Grrifiths, H. 2006. "The Effect of Salinity on Growth. Inorganic Ions and Dry Matter Partitioning in Sugar Beet Cultivars.” J. Agric. Sci. Technol. 8: 199-210.

[27] Munns, R., and Termaat, A. 1986. "Whole-Plant Responses to Salinity.” Aust. J. Plant Physiol. 13: 143-60.

[28] Yang, C., Jianaer, A., Li, C., Shi, C., and Wang, D. 2008. "Comparison of the Effects of Salt-Stress and Alkali-Stress on the Photosynthetic Production and Energy Storage of an Alkali-Resistant Halophyte Chlorisvirgata.” Photosynthetica. 46 (2): 273-8.

[29] Campbell, S. A., and Nishio, J. N. 2000. "Iron Deficiency Studies of Sugar Beet Using an Improved Sodium Bicarbonate-Buffered Hydroponics Growth System.” J. Plant Nut. 23: 741-57.

[30] Flowers, T. J., and Hajibagheri, M. A. 2001. "Salinity Tolerance in Hordeum vulgare: Ion Concentration in Root Cell of Cultivars Differing in Salt Tolerance.” Plant Soil 231 (1): 1-9.

[31] Qadir, M., Ghafoor, A., and Murata, G. 2001. "Amelioration Strategies for Saline-Sodic Soils: A Review.” Land Degrad. and Develop. 12: 357-86.

[32] Aisha, A. H., Rizk, F. A., Shaheen, A. M., and Abdel-Mouty, M. M. 2007. "Onion Plant Growth, Bulb Yield and Its Physical and Chemical Properties as Affected by Organic and Natural Fertilization.” Res. J. Agric. Biol. Sci. 3 (5): 380-8. 